ISSN: $1858-4837$

E-ISSN: 2598-019X

Volume 13, Nomor 2 (2018),

https://jurnal.uns.ac.id/region

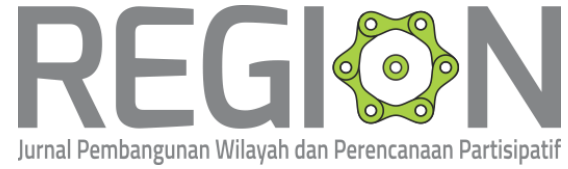

\title{
Faktor-faktor yang Mempengaruhi Pemilihan Sekolah Dasar dalam Mendukung Kota Surakarta Layak Anak
}

\author{
The Factors Influencing Elementary Schools Choices in Supporting \\ Surakarta as a Child-Friendly City
}

\section{Resty Darma Saputri ${ }^{a}$, Rufia Andisetyana Putri ${ }^{\text {b }}$, Erma Fitria Rinic}

\begin{abstract}
${ }^{a}$ Program Studi Perencanaan Wilayah dan Kota, Fakultas Teknik, Universitas Sebelas Maret ${ }^{b}$ Program Studi Perencanaan Wilayah dan Kota, Fakultas Teknik, Universitas Sebelas Maret cProgram Studi Perencanaan Wilayah dan Kota, Fakultas Teknik, Universitas Sebelas Maret

*Corresponding author's email: restydarmaa@gmail.com
\end{abstract}

\begin{abstract}
Abstrak
Pemenuhan kebutuhan anak akan fasilitas sosial menjadi salah satu urgensi dalam perkembangan kota mengingat penduduk pada usia anak memiliki hak yang sama dengan penduduk berusia dewasa. Tidak seperti penduduk berusia dewasa, pergerakan anak dapat dikatakan masih terbatas. Anak belum mampu untuk menjangkau kebutuhan mereka akan fasilitas sosial dengan menggunakan kendaraan. Oleh karena itu, idealnya pemenuhan kebutuhan akan fasilitas sosial anak harus dimulai dari unit lingkungan terkecil atau dapat disebut Neighbourhood Unit (NU). Salah satu prinsip Neighbourhood Unit yang ideal ialah pentingnya ketersediaan fasilitas sosial SD pada suatu Neighbourhood Unit. Rini et al. (2017) menyatakan bahwa 37,67\% atau lebih dari sepertiga penduduk anak usia SD di Kota Surakarta cenderung memilih sekolah yang berada di luar Neighbourhood Unit tempat tinggal mereka sendiri. Hal tersebut menunjukkan bahwa terdapat faktor-faktor yang mempengaruhi pemilihan Sekolah Dasar dalam mendukung Kota Surakarta layak anak. Berdasarkan analisis faktor yang telah dilakukan dengan menggunakan software SPSS, terbentuklah 3 kelompok faktor yang berisi beberapa sub-faktor. Kelompok faktor pertama yang merupakan faktor dominan merepresentasikan terpenuhinya indikator terkait sekolah ramah anak. Kelompok faktor kedua merepresentasikan lokasi dan jam belajar sekolah, sedangkan Kelompok faktor ketiga merepresentasikan fasilitas tambahan yang tidak disediakan oleh semua sekolah, seperti ketersediaan sarana dan prasarana transportasi umum dan adanya program makan siang di sekolah.
\end{abstract}

Kata Kunci: Faktor Pemilihan Sekolah Dasar, Kota Layak Anak, Neighbourhood Unit

\section{Abstract}

The fulfilment of the children's need for social facilities becomes an urgency in urban development since children has the same rights as the adult. Unlike the adult, the movement of children is still limited. Children have not been able to fulfil their needs for social facilities by means of vehicles. Therefore, ideally the fulfilment of the need for children's social facilities should start from the smallest environmental unit or can be called as Neighbourhood Unit (NU). One of the ideal Neighbourhood Unit Principles is the importance of the availability of social facilities such as elementary school in a Neighbourhood Unit. Rini et al. (2017) stated that $37.67 \%$ or more than one third of the population of elementary school children in Surakarta City tend to choose schools that are outside their own Neighbourhood Unit. It shows that there are factors influencing elementary school choices in supporting Surakarta as a child-friendly city. Based on the analysis of factors that had been done using SPSS software, formed 3 groups of factors that contain several sub-factors. The first factor group that is the dominant factor 
Resty Darma Saputri dkk, Faktor-faktor yang Mempengaruhi... represents the fulfilment related factor that is child-friendly school. The second factor group represents the school's location and hours, while the third factor group represents additional facilities which not provided by all schools, such as the availability of public transportation and availability of lunch program in school.

Keywords: Elementary schools choices factors, Child-friendly City, Neighbourhood Unit

\section{PENDAHULUAN}

Persentase populasi penduduk anak berusia 0-18 tahun di Indonesia pada tahun 2015 mencapai 34,53\% dari keseluruhan jumlah penduduk Indonesia (BPS Kota Surakarta, 2015). Bertolak dari fakta tersebut, pemenuhan kebutuhan anak akan fasilitas sosial menjadi salah satu urgensi dalam perkembangan kota mengingat penduduk pada usia anak memiliki hak yang sama dengan penduduk berusia dewasa. Tidak seperti penduduk berusia dewasa, pergerakan anak dapat dikatakan masih terbatas. Anak belum mampu untuk menjangkau kebutuhan mereka akan fasilitas sosial dengan menggunakan kendaraan. Oleh karena itu, idealnya pemenuhan kebutuhan akan fasilitas sosial anak harus dimulai dari unit lingkungan terkecil atau dapat disebut Neighbourhood Unit (NU), sehingga anak dapat menjangkaunya secara mandiri atau berjalan kaki dan anak tetap dapat memenuhi kebutuhannya akan fasilitas sosial dengan aman. Prinsip-prinsip Neighbourhood Unit yang ideal disampaikan oleh Clarence Perry (1929). Salah satunya ialah pentingnya ketersediaan fasilitas sosial SD pada suatu Neighbourhood Unit. SD harus tersedia di Neighbourhood Unit sehingga jarak tempuh anak menuju SD hanya berkisar antara 0,25 mil $(400 \mathrm{~m})$ dan hingga 0,5 mil $(800 \mathrm{~m})$ dan dapat ditempuh tanpa menyeberang jalan arteri Hal ini dikarenakan SD merupakan kebutuhan dasar anak dengan frekuensi kunjung harian sehingga anak dapat menjangkau Sekolah Dasar secara mandiri (berjalan kaki) dengan aman dan nyaman.

Kota Surakarta telah ditetapkan sebagai Kota Layak Anak kategori Nindya sejak tahun 2011 oleh Kementerian Pemberdayaan Perempuan dan Perlindungan Anak dan pada tahun 2017, Kota Surakarta mendapatkan menghargaan sebagai Kota Layak Anak 2017 untuk kategori Utama (Pemerintah Kota Surakarta, 2017). Penduduk anak usia sekolah dasar di Kota Surakarta pada tahun 2016 mencapai 106.600 anak atau setara dengan 20\% dari seluruh penduduk di Kota Surakarta yang berjumlah 514.171 jiwa. Hal ini mengindikasikan bahwa seharusnya, Kota Surakarta sudah mampu memenuhi kebutuhan anak akan fasilitas sosial seperti Sekolah Dasar dan taman bermain bahkan pada skala Neighbourhood Unit. Rini et al. (2017) menyatakan bahwa 37,67\% atau lebih dari sepertiga penduduk anak usia SD di Kota Surakarta cenderung memilih sekolah yang berada di luar 
Region, Vol. 13, No.2, Juli 2018: 152-168

Neighbourhood Unit tempat tinggal mereka sendiri. Hal tersebut menunjukkan bahwa terdapat faktor-faktor yang mempengaruhi pemilihan Sekolah Dasar dalam mendukung Kota Surakarta layak anak.

\section{TINJAUAN PUSTAKA}

\subsection{Konsep Kota Layak Anak}

Menurut UNICEF Innocenti Research Centre (2011), kota layak anak adalah kota yang dapat menjamin hak setiap anak sebagai warga kota untuk tidak dipandang sebelah mata. Kota layak anak (child friendly city) merupakan sebuah perwujudan dari Konvensi Hak Anak (Convention on the Rights of the Child) pada level lokal, yang berarti bahwa pada praktiknya, hak anak dapat tercermin pada kebijakan, hukum, program, maupun pembiayaan. Pada kota layak anak, anak merupakan agen aktif; aspirasi dan opini mereka turut mempengaruhi proses pengambilan keputusan kota (Unicef, 2011). Indikator Kota Layak Anak menurut Peraturan Menteri Kementerian Pemberdayaan dan Perlindungan Anak No. 12 Tahun 2011 terdiri dari 6 indikator kelembagaan dan 25 indikator subtansi yang dikelompokkan dalam 5 klaster hak anak yaitu :

- Hak Sipil dan Kebebasan

- Lingkungan Keluarga dan Pengasuhan Alternatif

- Kesehatan dan Kesejahteraan Dasar

- Pendidikan, pemanfaatan waktu luang dan kegiatan budaya

- Perlindungan khusus

\subsection{Konsep Neighbourhood Unit}

Teori Neighborhood unit muncul pertama kalinya pada tahun 1929 dari pemikiran Clarence Arthur Perry. Gagasan tersebut membuat dunia sepakat bahwa Neighborhood unit adalah model pemukiman yang paling ideal. Neighbourhood Unit adalah suatu lingkungan fisik perumahan dalam kota dengan batasan yang jelas, tersedia pelayanan fasilitas sosial untuk tingkat rendah, untuk melayani sejumlah penduduk, di mana terdapat hubungan kerjasama yang dilandasi oleh control sosial dan rasa komunitas (Porteous, 1977; dalam Suryanto, 1989:47). Neighbourhood Unit dikenal sebagai suatu konsep untuk merencanakan suatu lingkungan yang berlandaskan suatu pemikiran sosial psikologis sebagai jawaban atas permasalahan yang terjadi pada saat itu, yaitu penurunan kualitas kehidupan masyarakat di Negara-negara industri. Menurut Perry, Neighbourhood Unit yang ideal akan merangkum seluruh fasilitas publik dan kondisi-kondisi yang 
Resty Darma Saputri dkk, Faktor-faktor yang Mempengaruhi...

diperlukan oleh rata-rata keluarga bagi kenikmatan dan kewajaran hidup di sekitar rumah mereka. Selanjutnya, Perry menguraikan 6 prinsip dalam merencanakan Neighbourhood Unit (Rohe and Gates, 1985:26):

1. Size (ukuran)

2. Boundaries (batas)

3. Open Space (ruang terbuka)

4. Institution Sites (area-area institusi)

5. Local Shops (pertokoan setempat)

6. Internal Street System (sistem jalan internal)

\subsection{Kriteria Sekolah Dasar Ideal sebagai fasiliitas Neighbourhood Unit untuk Menunjang Kota Layak Anak}

Dari beberapa teori terkait, didapatkan sintesis kriteria sekolah dasar ideal sebagai fasilitas neighbourhood unit dalam mendukung kota layak anak, di antaranya ialah lokasi sekolah yang harus berdekatan dengan rumah (Clarence Perry, 1929; Unicef, 201 1; Indikator KLA, 2011), tersedianya sarana dan prasarana ramah anak (Kementerian PPPA, 2015; Patilima, 2008), efektivitas waktu belajar mengajar (Patilima, 2008), pelaksanaan proses belajar mengajar yang ramah anak (Kementerian PPPA, 2015), adanya partisipasi anak dalam proses kegiatan belajar mengajar (Kementerian PPPA, 2015; Patilima, 2008), adanya program makan siang bersama di sekolah (Patilima, 2008), adanya penerapan kebijakan mengenai sekolah ramah anak di sekolah (Patilima, 2008), pendidik dan tenaga kependidikan terlatih hak-hak anak (Kementerian PPPA, 2015), dan adanya partisipasi pihak terkait dalam perwujudan sekolah ramah anak (Kementerian PPPA, 2015)

\subsection{Faktor yang Mempengaruhi Pemilihan Sekolah Dasar}

Dari berbagai sumber, dapat didentifikasi faktor-faktor yang mempengaruhi pemilihan sekolah dasar yakni kualitas guru (R. Septhevian, 2014), pendidikan agama yang diterapkan di sekolah (R. Septhevian, 2014; S. Andrayana, 2009; N. Khasanah, 2012), fasilitas (R. Septhevian, 2014; S. Andrayana, 2009; N. Khasanah, 2012), biaya sekolah (S. Andrayana, 2009), kondisi kebersihan dan ketenangan lingkungan sekolah (R. Septhevian, 2014), keamanan sekolah (R. Septhevian, 2014), citra sekolah (R. Septhevian, 2014), prestasi sekolah dan prestasi murid (S. Andrayana, 2009), lokasi sekolah (S. Andrayana, 2009; N. Khasanah, 2009), ekstrakulikuler (S. Andrayana, 2009), promosi yang dilakukan sekolah (Kristiani, 2016), kualitas pelayanan dalam mendukung kegiatan belajar mengajar (Kristiani, 
Region, Vol. 13, No.2, Juli 2018: 152-168

2016), budaya yang diterapkan di sekolah sehari-hari (N. Khasanah, 2009), dan kualitas pelanggan (N. Khasanah, 2009). Pada proses sintesis faktor yang mempengaruhi pemilihan sekolah dasar, terdapat beberapa faktor yang dieliminasi karena dianggap tidak relevan dengan batasan substansi pada penelitian ini terkait kota layak anak. Sehingga faktor yang terpilih ialah fasilitas, ekstrakulikuler, kualitas guru, lokasi sekolah, dan keamanan sekolah.

\subsection{Sintesis Variabel}

Dari kriteria sekolah ideal dan faktor pemilihan sekolah dasar, dilakukan proses sintesis variabel dengan menyandingkan kriteria pada tiap teori sehingga didapatkan variabel yang akan digunakan pada penelitian ini adalah sebagai berikut.

Tabel 1. Sintesis Variabel Faktor yang Mempengaruhi Pemilihan Sekolah Dasar dalam Menunjang Kota Layak Anak

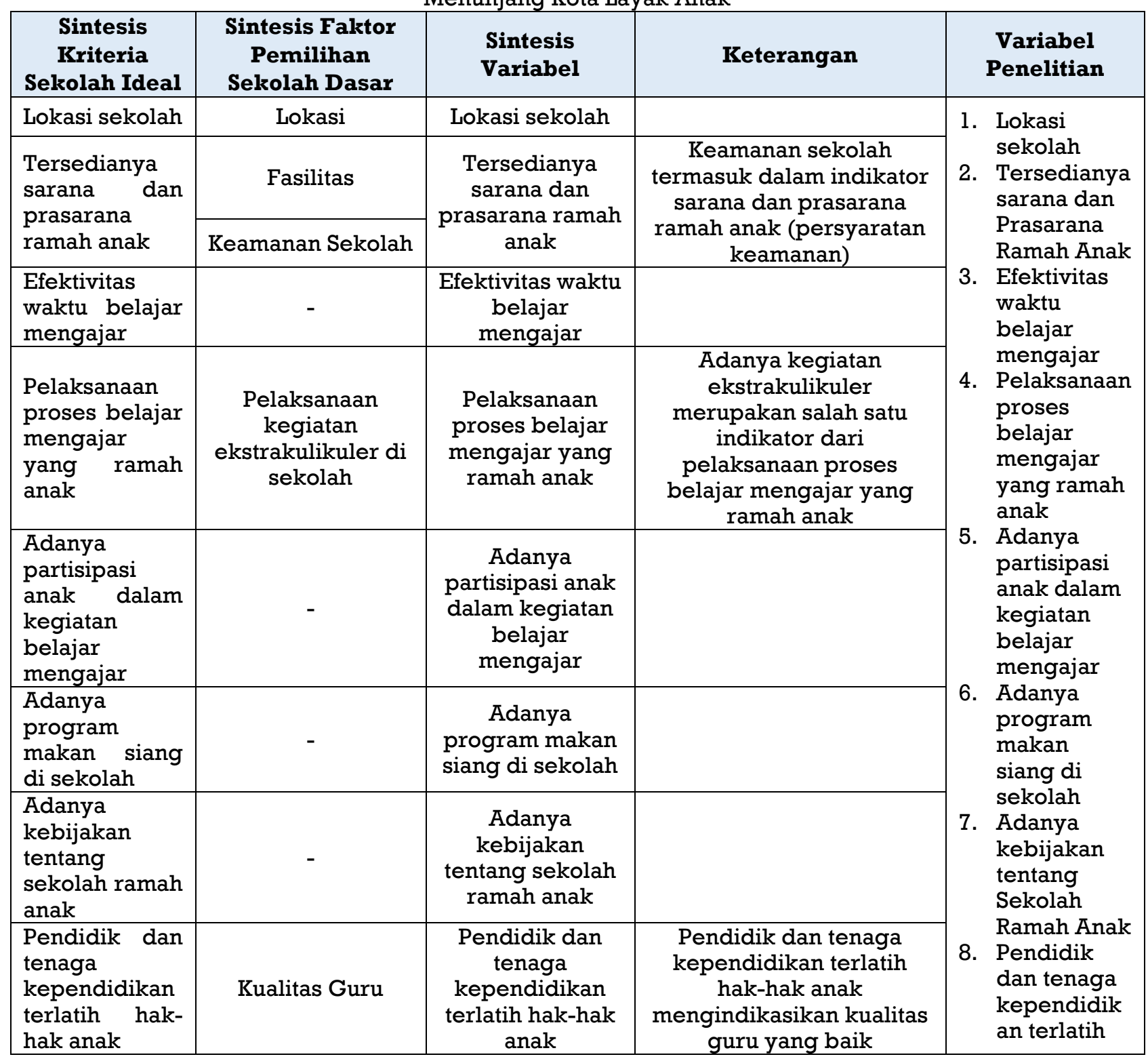


Resty Darma Saputri dkk, Faktor-faktor yang Mempengaruhi...

\begin{tabular}{|l|c|c|c|}
\hline & & hak-hak \\
Partisipasi & & anak \\
orang & Partisipasi orang & tua/wali, & 9. Partisipasi \\
tua/wali, & lembaga & orang \\
lembaga & tua/wali, \\
masyarakat, & masyarakat, & lembaga \\
dunia usaha, & - & dunia usaha, & masyakat, \\
pemangku & pemangku & dunia \\
kepentingan & kepentingan & usaha, \\
lainnya, dan & & lainnya, dan & pemangku \\
alumni & alumni & kepentinga \\
& & & n lainnya, \\
& & & dan alumni \\
\hline
\end{tabular}

Sumber: Peneliti, 2018

\section{METODE}

Pendekatan yang digunakan pada penelitian ini ialah pendekatan deduktif dengan jenis penelitian kualitatif. Proses pengumpulan data dilakukan dengan melakukan survei primer berupa penyebaran kuesioner kepada orang tua/wali murid untuk mengetahui faktor yang mempengaruhi pemilihan sekolah dasar menurut persepsi orang tua/wali murid dan kepala sekolah untuk mengetahui karakteristik sekolah. Sampel sekolah yang digunakan pada penelitian ini ialah sebanyak 130 sampel, sedangkan jumlah sampel responden orang tua/wali murid adalah sebesar 161 sampel. Data tersebut kemudian dianalisis dengan teknik analisis faktor pada software SPSS. Kerangka analisis pada penelitian ini adalah sebagai berikut.
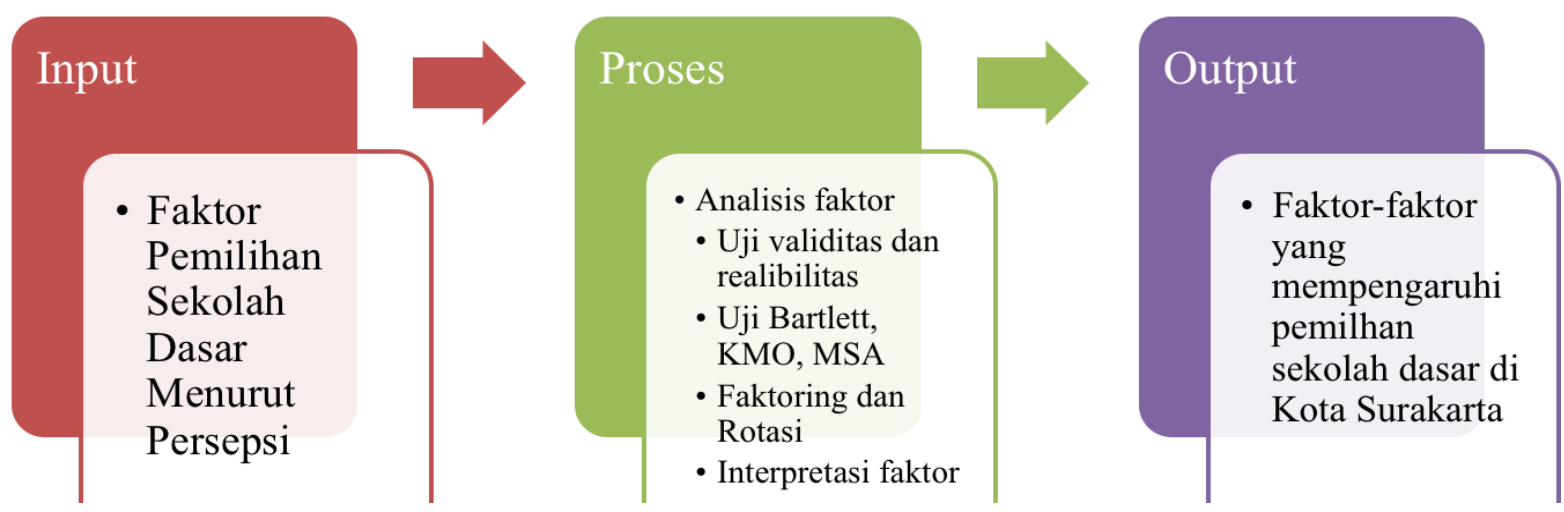

Gambar 1. Kerangka Analisis Penelitian

Sumber: Peneliti, 2018

\section{HASIL PENELITIAN DAN PEMBAHASAN}

\subsection{Gambaran Umum Kota Surakarta}

Kota Surakarta secara geografis terletak antara $110^{\circ} 45^{\prime} 15^{\prime \prime}$ dan $110^{\circ} 45^{\prime} 35^{\prime \prime}$ Bujur Timur dan antara $7^{\circ} 36^{\prime}$ dan $7^{\circ} 56^{\prime}$ Lintang Selatan. Kota Surakarta merupakan salah satu kota besar yang terletak di Provinsi Jawa Tengah dengan luas wilayah $44,04 \mathrm{~km}^{2}$. Kota Surakarta terbagi atas 5 kecamatan, yakni Kecamatan Laweyan, Serengan, Pasar Kliwon, Jebres, dan Banjarsari. 


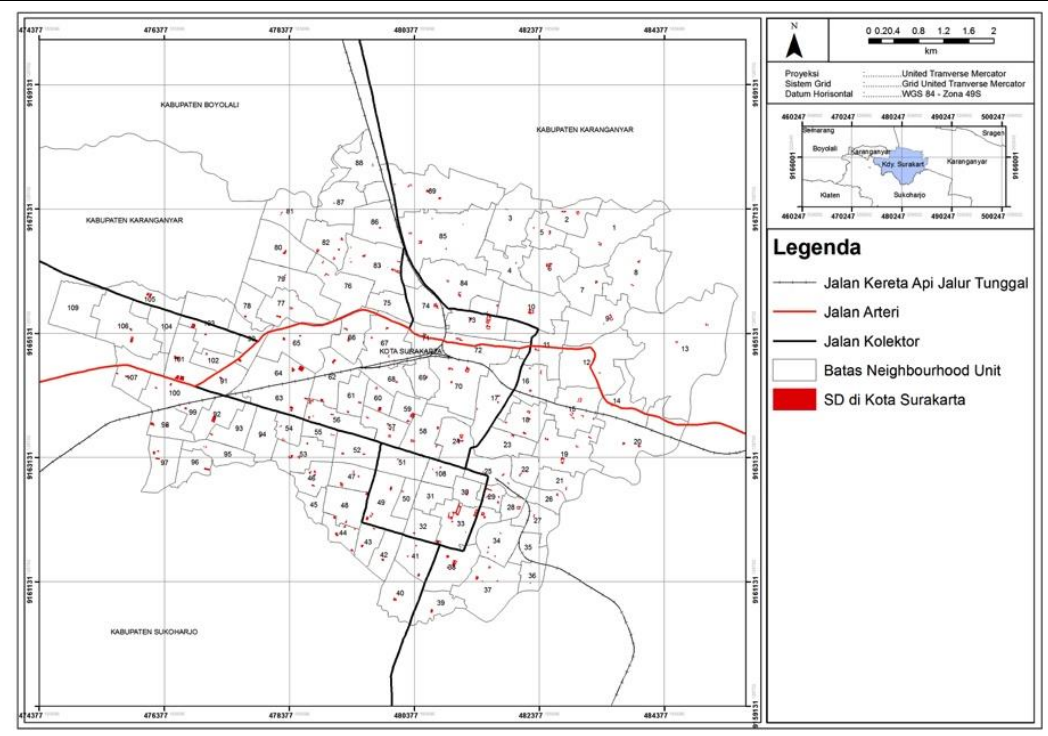

Gambar 2. Ruang Lingkup Wilayah Penelitian

(Peta RBI Bakosurtanal, 2012; Mulyanto et. al, 2017)

Pada 2006, Kota Surakarta merupakan salah satu dari 5 Kabupaten/Kota (yakni Kota Surakarta, Kabupaten Gorontalo, Kota Jambi, Kabupaten Sidoharjo, dan Kabupaten Kutai Kartanegara) yang ditunjuk oleh Menteri Negara Pemberdayaan Perempuan RI sebagai pilot proyek pengembangan model KLA di Indonesia. Pada Juli 2017, Kota Surakarta lalu menyandang Kota Layak Anak kategori Madya berkat dikeluarkannya Peraturan Daerah Kota Surakarta Nomor 4 Tahun 2012 tentang Perlindungan Anak.

\subsection{Karakteristik Faktor yang Mempengaruhi Pemilihan Sekolah Dasar}

\subsubsection{Lokasi Sekolah}

Dari hasil penyebaran kuesioner, dapat dilihat bahwa jarak dari rumah ke sekolah sangat beragam dengan yang paling dekat sekitar 50 meter dan jarak terjauh mencapai $12.000 \mathrm{~m}$. Diagram besarnya jarak responden dari rumah ke sekolah dapat dilihat pada gambar di bawah ini.

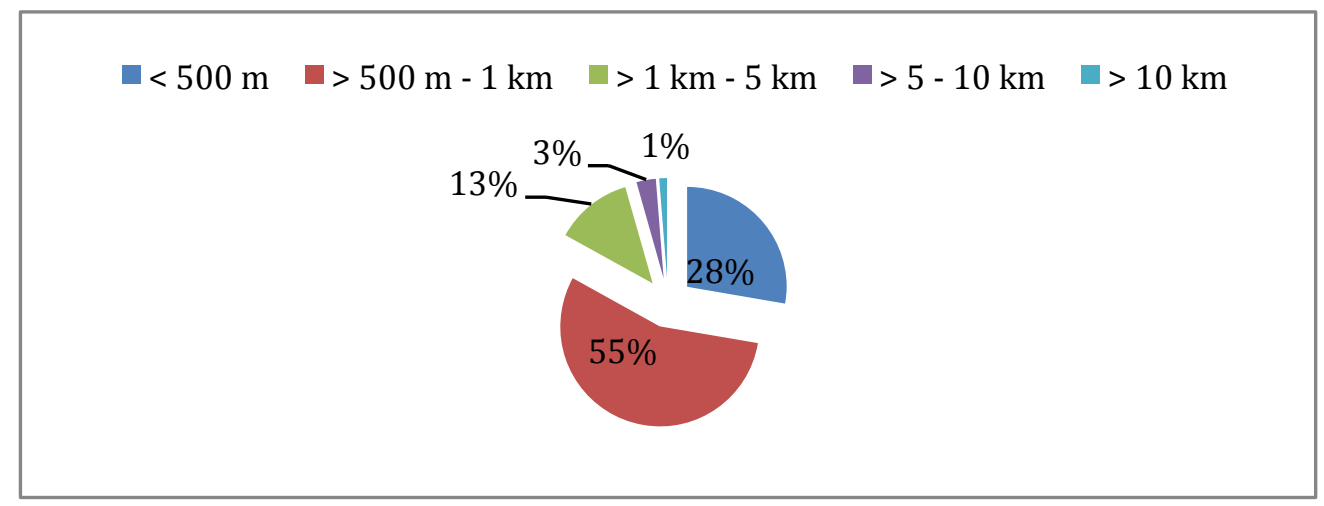

Gambar 3 Diagram Rata-rata Besaran Jarak dari Rumah ke Sekolah 
Resty Darma Saputri dkk, Faktor-faktor yang Mempengaruhi...

Dapat disimpulkan bahwa mayoritas jarak tempuh responden dari rumah ke sekolah adalah sebesar lebih dari 500 meter hingga $1 \mathrm{~km}$. Jarak ini tergolong sebagai jarak yang mudah untuk dijangkau oleh anak.

\subsubsection{Ketersediaan Sarana dan Prasarana Ramah Anak}

Ketersediaan sarana dan prasarana ramah anak pada sekolah dasar di Kota Surakarta diasumsikan dapat dilihat pada penilaian status akreditasi masingmasing sekolah dasar mengingat salah satu hal yang dinilai pada proses akreditasi meliputi standar sarana prasarana yang di dalamnya termasuk sarana prasarana ramah anak. Dari data penilaian standar sarana prasarana sekolah yang ada, didapatkan persentase sekolah yang sudah memenuhi standar sarana prasarana ramah anak di Kota Surakarta adalah sebagai berikut.

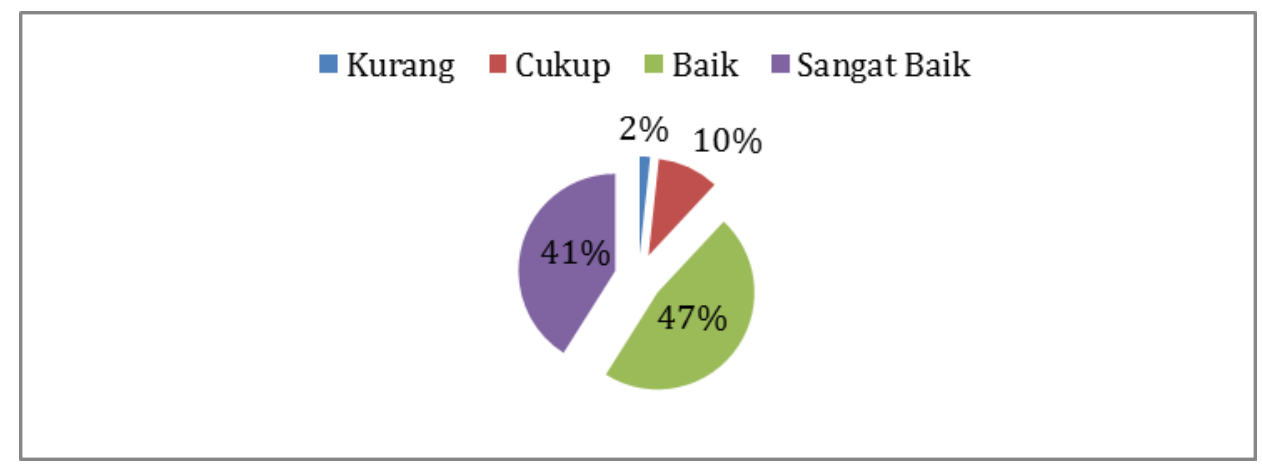

Gambar 4 Diagram Ketersediaan Sarana dan Prasarana Ramah Anak

Dari diagram di atas, dapat disimpulkan bahwa $47 \%$ dari seluruh sampel sekolah dasar di Kota Surakarta sudah menyediakan sarana dan prasarana ramah anak yang memenuhi standar dengan baik. Berikut merupakan peta persebaran kondisi pemenuhan sarana dan prasarana ramah anak

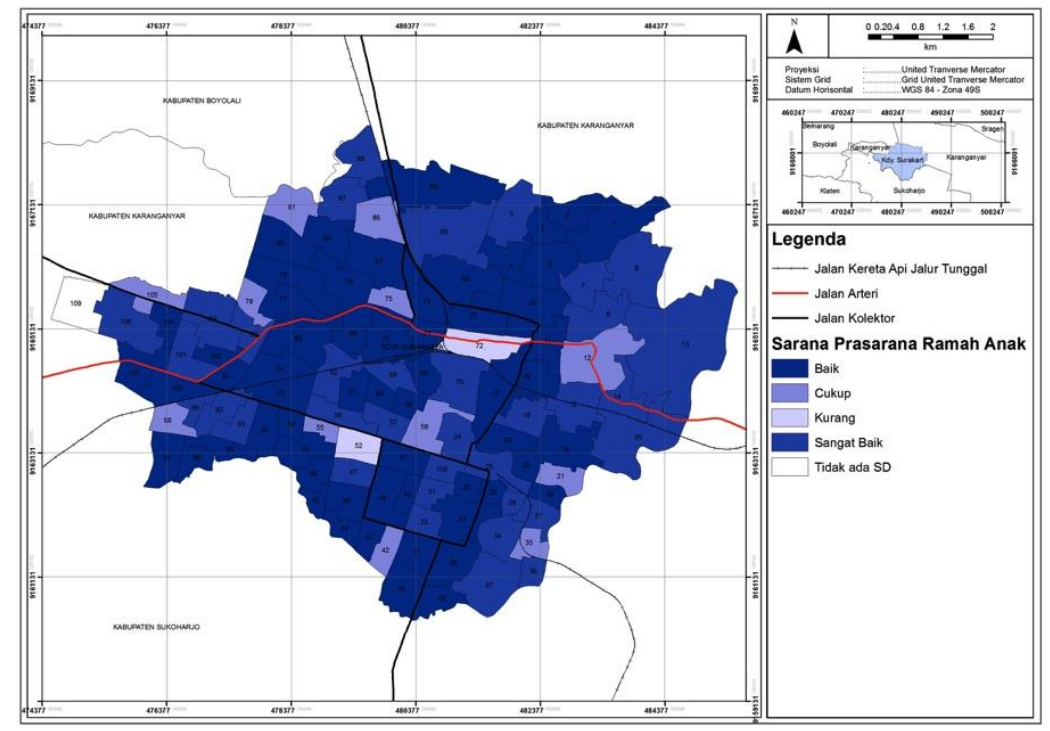

Gambar 5 Peta Persebaran Kondisi Pemenuhan Sarana dan Prasarana Ramah Anak (Badan Akreditasi Nasional Sekolah/Madrasah, 2014-2018)

\subsubsection{Efektivitas Waktu Belajar Mengajar}


Region, Vol. 13, No.2, Juli 2018: 152-168

Sebagian besar sekolah di Kota Surakarta menerapkan jam belajar yang berbeda bagi siswa kelas 1 hingga kelas 6. Menurut wawancara ke beberapa sampel sekolah, siswa kelas 1 hanya belajar hingga sekitar jam 10, sedangkan siswa kelas atas memiliki jam belajar hingga jam 12. Namun, di beberapa sekolah yang menerapkan kebijakan full day school bagi siswa kelas atas, menambah jam belajar hingga sekitar pukul 15.00 sore. Tetapi sekolah ini hanya menerapkan 5 hari belajar saja dan meliburkan siswanya di hari sabtu. Dapat dikatakan bahwa seluruh sekolah dasar di Kota Surakarta telah menggunakan waktu belajar mengajar yang efektif.

\subsubsection{Pelaksanaan Proses Belajar Mengajar yang Ramah Anak}

Pelaksanaan proses belajar mengajar yang ramah anak diasumsikan dapat dilihat dari penilaian status akreditasi, mengingat bahwa salah satu standar yang harus dipenuhi pada saat penilaian akreditasi ialah standar proses yang terkait dengan proses belajar mengajar yang ramah anak. Persentase sekolah yang telah menerapkan proses belajar mengajar ramah anak di Kota Surakarta dapat dilihat pada diagram berikut.

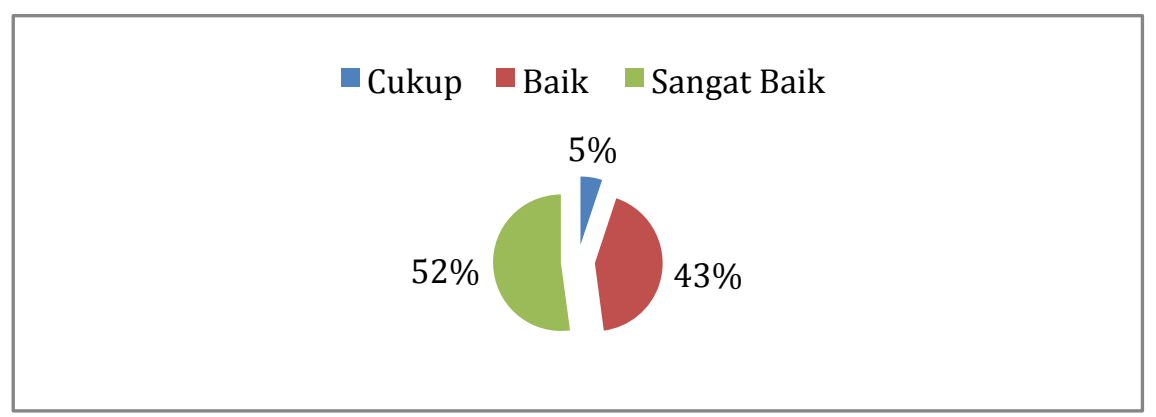

Gambar 6 Diagram Pelaksanaan Proses Belajar Mengajar yang Ramah Anak

Dari diagram tersebut dapat disimpulkan bahwa sekolah dasar di Kota

Surakarta telah menerapkan proses belajar mengajar yang ramah anak karena hampir sebagian besar telah mendapatkan penilaian sangat baik pada standar proses belajar mengajar, bahkan tidak ada yang mendapat penilaian kurang. Peta persebaran sekolah yang telah menerapkan proses belajar mengajar ramah anak berdasarkan kualifikasi kualitas di Kota Surakarta adalah sebagai berikut. 


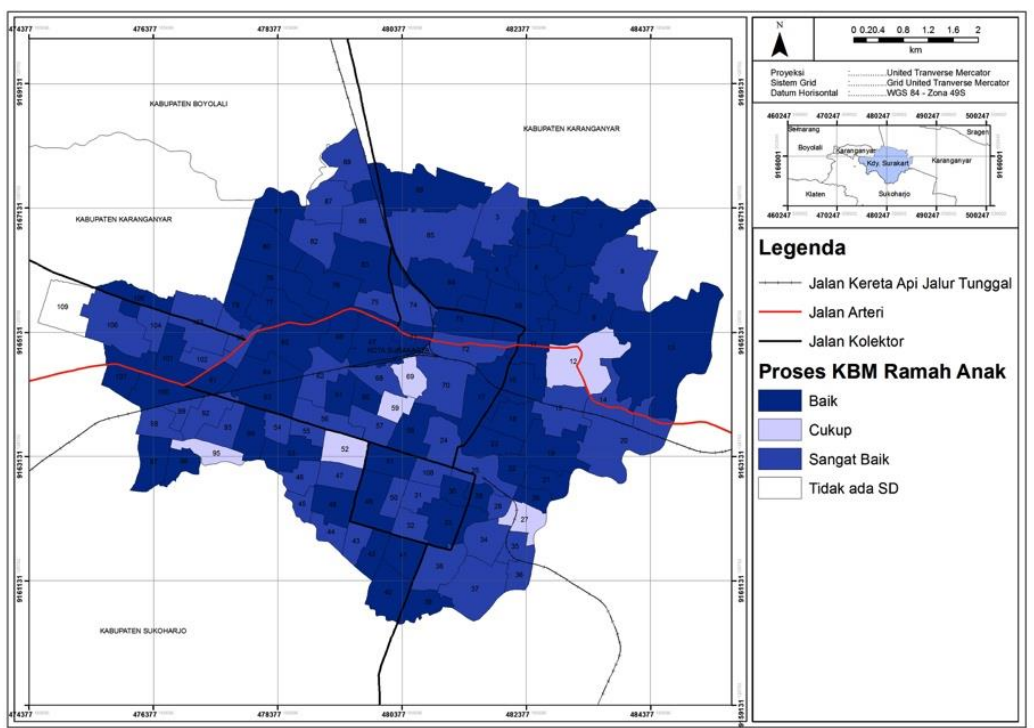

Gambar 7 Peta Persebaran Proses Belajar Mengajar Ramah Anak (Badan Akreditasi Nasional Sekolah/Madrasah, 2014-2018)

\subsubsection{Adanya Partisipasi Anak dalam Kegiatan Belajar Mengajar}

Persentase sekolah dasar di Kota Surakarta yang telah melibatkan partisipasi anak adalah sebagai berikut. Data tersebut ditampilkan pada diagram di bawah ini.

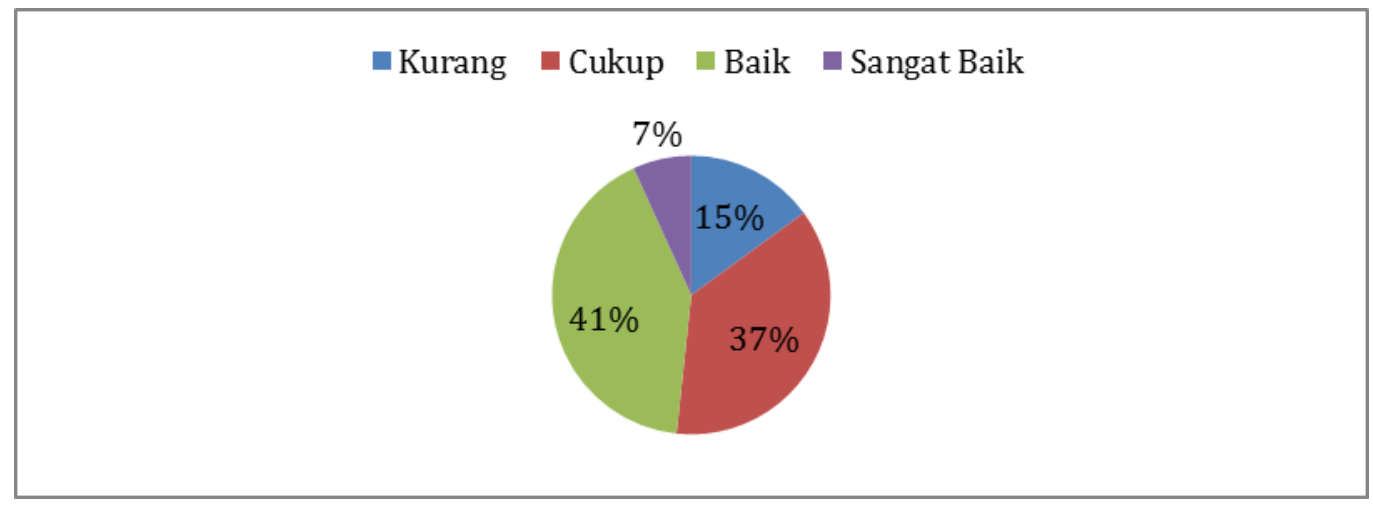

Gambar 8 Diagram Pelaksanaan Partisipasi Anak

Melalui diagram di atas dapat disimpulkan bahwa sebagian besar sekolah di Kota Surakarta telah melibatkan partisipasi anak dalam kegiatan belajar mengajar dengan baik. Hanya 14\% sekolah dari keseluruhan sampel yang masih kurang dalam melibatkan partisipasi anak. Peta persebaran adanya partisipasi anak dalam kegiatan belajar mengajar berdasarkan kualifikasi kualitas di Kota Surakarta adalah sebagai berikut. 


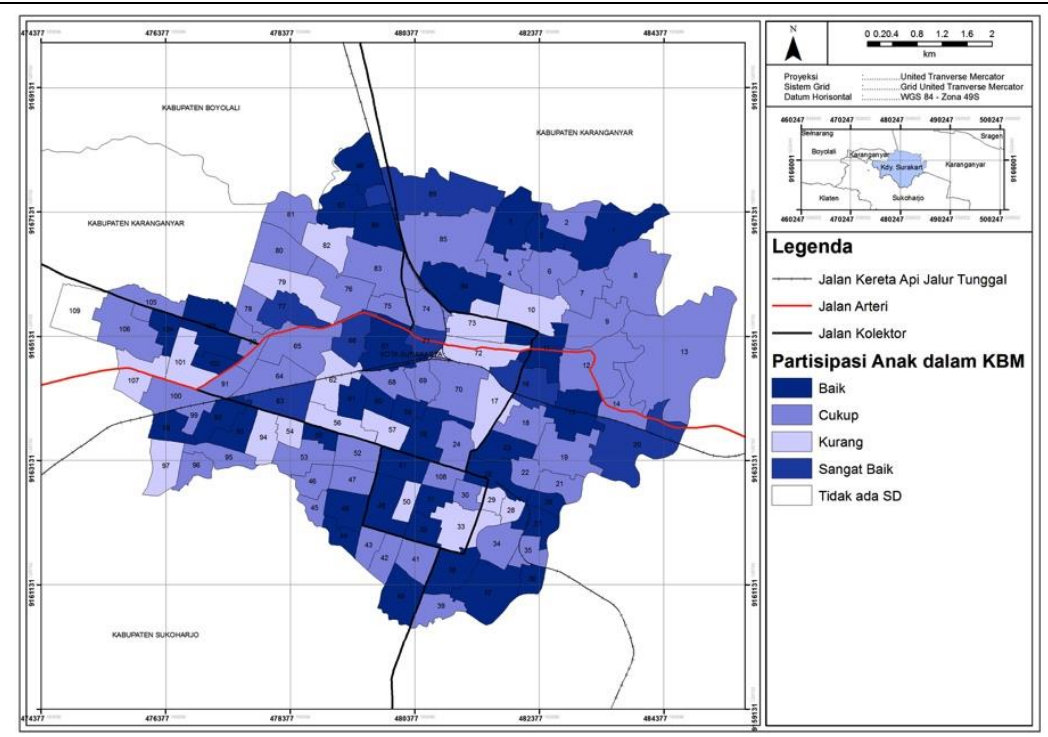

Gambar 9 Peta Persebaran Pelaksanaan Partisipasi Anak (Hasil Wawancara, 2018)

\subsubsection{Adanya Program Makan Siang}

Persentase perbandingan banyaknya sekolah dasar di Surakarta yang menyediakan program makan siang bersama dan tidak dapat dilihat pada tabel berikut.

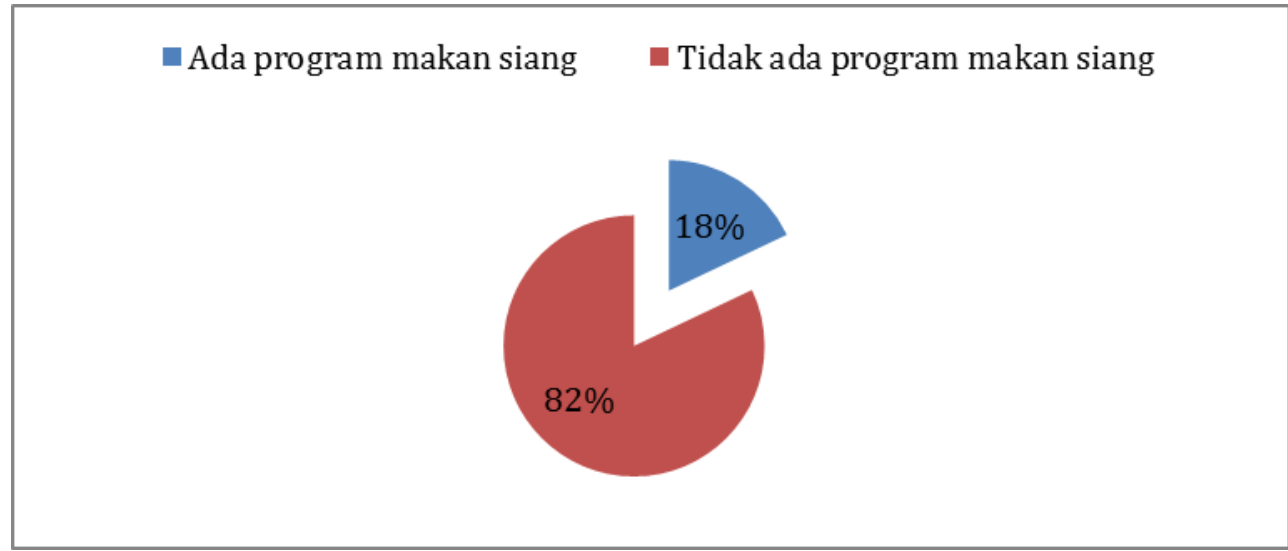

Gambar 10 Persentase Adanya Program Makan Siang di Sekolah Dasar Kota Surakarta Melalui diagram di atas dapat disimpulkan bahwa mayoritas sekolah dasar di Kota Surakarta belum menyediakan program makan siang di sekolah. Menurut hasil wawancara ke beberapa kepala sekolah, hal ini disebabkan karena pihak sekolah merasa belum membutuhkan adanya program tersebut, mengingat siswa sekolah dasar hanya belajar hingga jam 12 siang sehingga bisa menikmati makan siang di rumah masing-masing. Sekolah yang menerapkan program makan siang merupakan sekolah yang menerapkan sistem full day school atau jam belajar hingga pukul 15.00 sehingga siswa membutuhkan adanya program makan siang di sekolah. Persebaran adanya program makan siang di sekolah dasar Kota Surakarta ditampilkan pada peta berikut. 


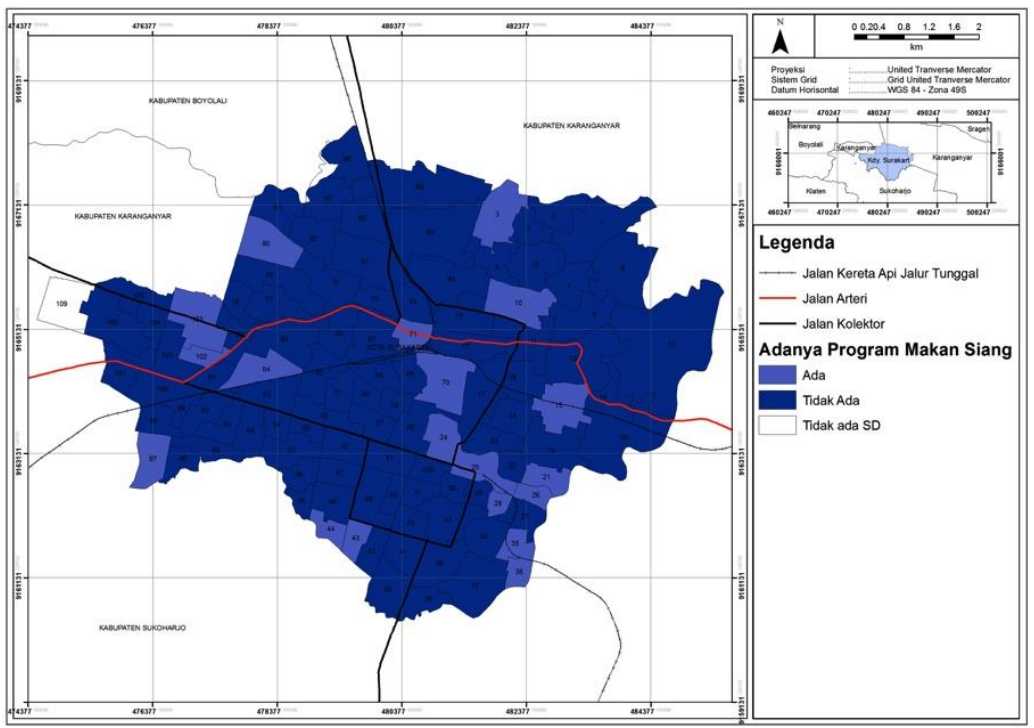

Gambar 11 Peta Persebaran Adanya Program Makan Siang (Hasil Wawancara, 2018)

\subsubsection{Adanya Kebijakan tentang Sekolah Ramah Anak}

Kebijakan mengenai sekolah ramah anak memiliki 21 indikator. Melalui hasil wawancara ke beberapa sampel sekolah, didapatkan hasil persentase sekolah yang telah menerapkan kebijakan sekolah ramah anak. Jika sekolah tersebut telah memenuhi 16-21 indikator, maka dapat dikatakan sekolah tersebut telah menerapkan kebijakan sekolah ramah anak dengan sangat baik. Jika sekolah tersebut menerapkan 10-15 indikator, maka sekolah tersebut dapat dikategorikan telah menerapkan kebijakan sekolah ramah anak dengan baik. Jika sekolah hanya menerapkan 5-9 indikator, maka sekolah tersebut dianggap cukup dalam menerapkan kebijakan sekolah ramah anak, sedangkan jika sekolah hanya menerapkan kurang dari 4 indikator, maka sekolah tersebut dinilai kurang dalam menerapkan kebijakan sekolah ramah anak. Persentase tersebut ditampilkan pada diagram berikut.

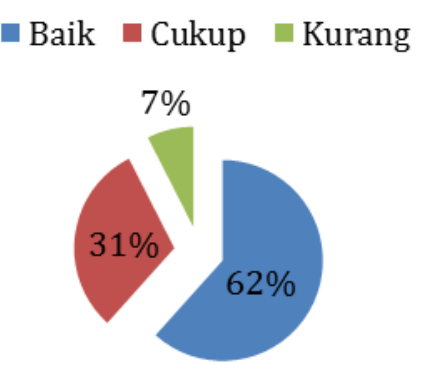

Gambar 12 Persentase Sekolah yang Telah Menerapkan Kebijakan Sekolah Ramah Anak

Dari diagram di atas, dapat ditarik kesimpulan bahwa 62\% sekolah di Kota Surakarta telah menerapkan kebijakan sekolah ramah anak dengan baik. Hanya sebesar 7\% yang masih kurang dalam penerapan kebijakan ramah anak. 


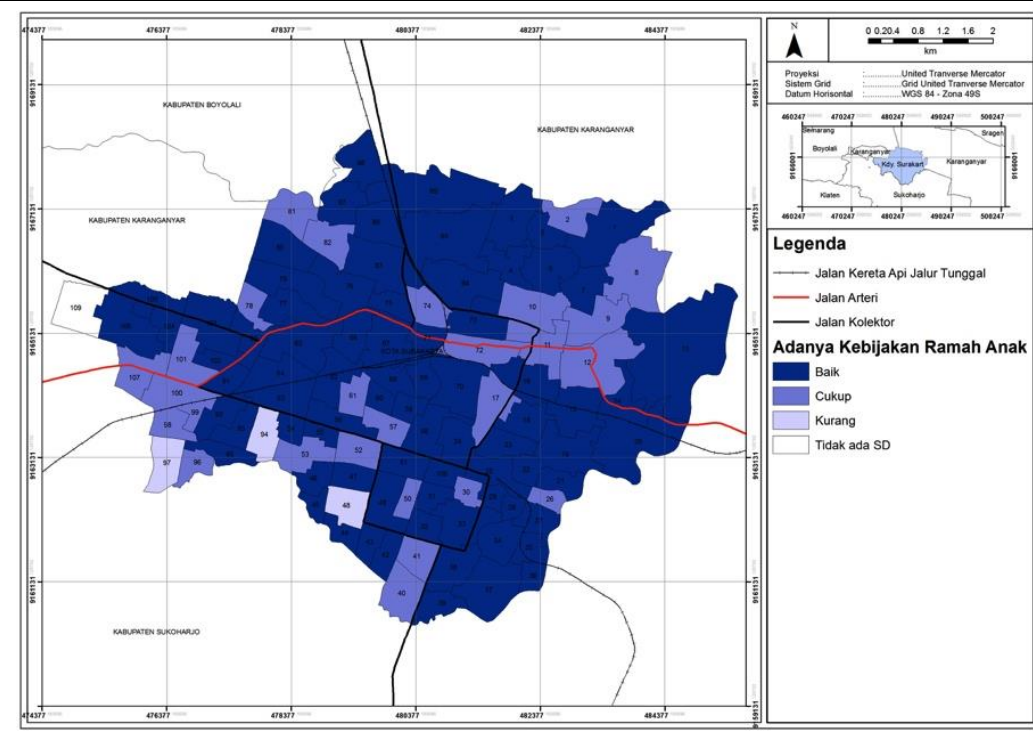

Gambar 13 Peta Penerapan Kebijakan Ramah Anak (Hasil Wawancara, 2018)

\subsubsection{Pendidik dan Tenaga Kependidikan Terlatih Hak-hak Anak}

Menurut wawancara yang dilakukan ke sampel sekolah, sejauh ini belum ada pelatihan dari pihak terkait mengenai hak-hak anak kepada pendidik atau tenaga kependidikan.

\subsubsection{Adanya Partisipasi Berbagai Pihak dalam Perwujudan Sekolah Ramah} Anak

Partisipasi berbagai pihak mulai dari orang tua/wali, lembaga masyarakat, dunia usaha, pemangku kepentingan lainnya, dan alumni dalam perwujudan sekolah ramah anak di Kota Surakarta dapat dikatakan masih minim. Dari total 133 kuesioner yang disebar ke sampel sekolah, hanya 15 sekolah yang sudah melibatkan partisipasi berbagai pihak atau hanya sekitar 11,28\%. Bentuk partisipasinya pun sama, yakni adanya Paguyuban Among Siswa dari wali murid dan melakukan pertemuan setidaknya sebulan sekali untuk mendiskusikan tumbuh kembang maupun masalah yang dihadapi anak di sekolah. Peta persebaran ada atau tidaknya partisipasi pihak terkait dalam perwujudan sekolah ramah anak di Kota Surakarta adalah sebagai berikut. 


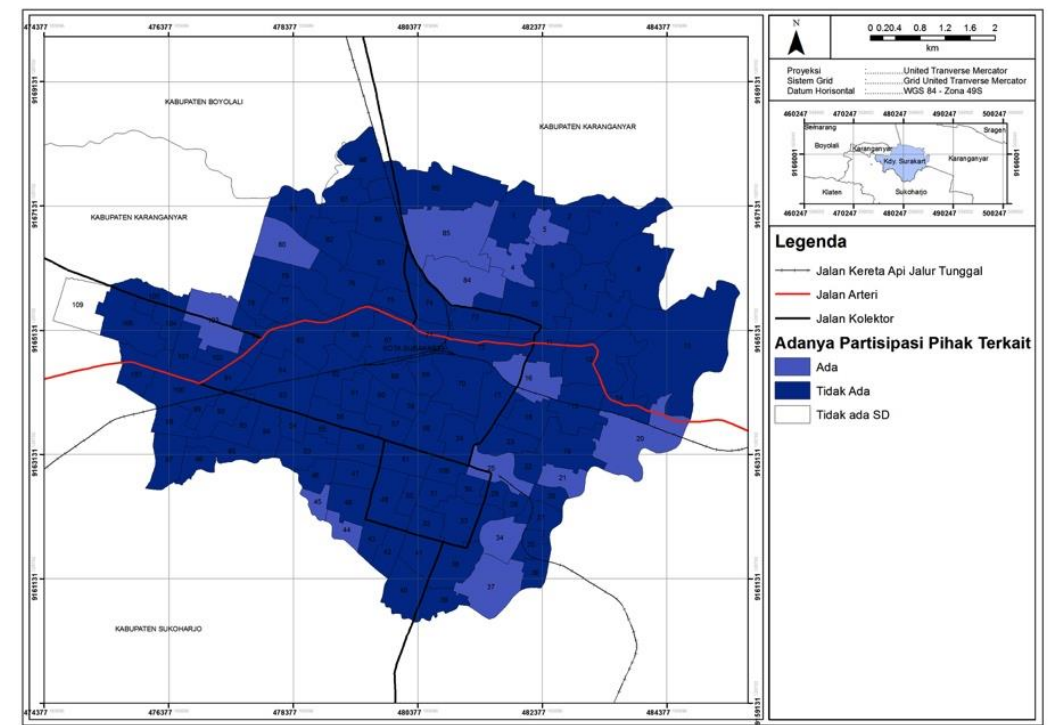

Gambar 14 Peta Persebaran Sekolah yang telah Menerapkan Partisipasi Pihak Terkait dalam Perwujudan Sekolah Ramah Anak

(Hasil Wawancara, 2018)

\subsection{Analisis Faktor}

Tabel 2. Tabel Rotated Component Matrix Rotated Component Matrix ${ }^{a}$

\begin{tabular}{|c|c|c|c|}
\hline & \multicolumn{3}{|c|}{ Component } \\
\hline & 1 & 2 & 3 \\
\hline Jarak_dari_Rumah & -.011 & .732 & .303 \\
\hline Sekolah_Mudah_Diakses & .201 & .801 & .264 \\
\hline Ketersediaan_Transportasi_Umum & .047 & .410 & 671 \\
\hline Lokasi Sekolāh Aman Nyāman & .276 & .697 & -.152 \\
\hline Ketersediaan_Sarpras_Ramah_Anak & .683 & .471 & -.144 \\
\hline Efektivitas_Waktu_Belajar_Mengajar & .459 & .597 & -.205 \\
\hline Proses_Bēajar_Mengajar_Ramah_Anak & 639 & .555 & -.026 \\
\hline Adanya_Partisipasi_Anak_dalam_KBM & .707 & .198 & .244 \\
\hline Adanya_Program_Makan_Siang & .211 & -.119 & .761 \\
\hline Adanya_Kebijakañ_Sekolah_Ramah_Anak & .758 & .262 & .156 \\
\hline Pendidik_Terlatih_Hak_Anak & .794 & .109 & .088 \\
\hline Partisipasi_Pihak_Terkait_dalam_Perwujudan_SRA & .814 & -.006 & .109 \\
\hline
\end{tabular}

Extraction Method: Principal Component Analysis.

Rotation Method: Varimax with Kaiser Normalization. ${ }^{\mathrm{a}}$

a. Rotation converged in 8 iterations.

Sumber: Output SPSS, 2018

Berdasarkan analisis faktor yang telah dilakukan dengan menggunakan software SPSS seperti yang ditampilkan pada tabel di atas, terbentuklah 3 kelompok faktor yang berisi beberapa sub-faktor. Kelompok faktor pertama dapat dikatakan sebagai kelompok faktor yang paling dominan terhadap keputusan pemilihan sekolah dasar di Kota Surakarta. Kelompok faktor pertama lebih merepresentasikan terpenuhinya indikator terkait sekolah ramah anak dengan sub-faktor ketersediaan sarana dan prasarana ramah anak, proses belajar mengajar yang ramah anak, adanya partisipasi anak dalam kegiatan belajar mengajar, adanya kebijakan sekolah ramah anak, pendidik dan tenaga 
Region, Vol. 13, No.2, Juli 2018: 152-168

kependidikan terlatih hak-hak anak, dan adanya partisipasi pihak terkait dalam perwujudan sekolah ramah anak. Jika dikaitkan dengan fakta yang terjadi di lapangan, belum semua sekolah dasar di Kota Surakarta memenuhi indikatorindikator yang terdapat pada tiap sub-faktor di kelompok faktor satu. Hasil ini juga mendukung hipotesis yang disebutkan pada latar belakang penelitian bahwa terdapat faktor lain selain besarnya jarak dari rumah ke sekolah dalam keputusan pemilihan sekolah dasar, dan faktor tersebut ialah terpenuhinya indikator sekolah ramah anak di sekolah dasar yang dituju.

Kelompok faktor kedua merepresentasikan lokasi dan jam belajar sekolah, dengan sub-faktor jarak dari rumah ke sekolah, tingkat aksesibilitas sekolah, lokasi sekolah aman dan nyaman, dan efektivitas waktu belajar mengajar. Berdasarkan pengamatan yang dilakukan di lapangan, lokasi sekolah yang dipilih oleh orang tua/wali murid masih tergolong dalam lokasi sekolah yang dapat dijangkau oleh anak. Sekolah di Kota Surakarta pun mayoritas memiliki tingkat aksesibilitas yang tinggi serta jam belajar mengajar yang efektif.

Kelompok faktor ketiga merepresentasikan fasilitas tambahan yang tidak disediakan oleh semua sekolah, yakni ketersediaan sarana transportasi umum dan adanya program makan siang di sekolah. Kelompok faktor ketiga tidak terlalu berpengaruh dalam keputusan pemilihan sekolah dasar bila dibandingkan dengan kedua kelompok faktor sebelumnya. Dilihat dari kenyataan di lapangan, memang tidak semua sekolah dilewati oleh rute transportasi umum dan hal itu tidak menjadi faktor penting bagi orang tua/wali murid karena mayoritas anak di Kota Surakarta memilih untuk berjalan kaki, bersepeda atau diantar orang tua mereka ke sekolah. Sub-faktor kedua yakni adanya program makan siang juga tidak menjadi faktor penting karena anak cenderung menikmati makan siang mereka di rumah.

Secara keseluruhan, dapat disimpulkan bahwa faktor yang paling berpengaruh dalam keputusan pemilihan sekolah dasar ialah faktor yang terkait dengan terpenuhinya indikator sekolah ramah anak. Hal ini kurang sesuai dengan teori terkait neighbourhood unit layak anak yang menyatakan bahwa seharusnya lokasi sekolah (Perry, 1929; S. Andrayana, 2009; N. Khasanah, 2009), menjadi faktor utama yang mempengaruhi keputusan orang tua dalam memilih sekolah dasar.

\section{KESIMPULAN}

Berdasarkan analisis faktor yang telah dilakukan dengan menggunakan software SPSS, terbentuklah 3 kelompok faktor yang berisi beberapa sub-faktor. Kelompok faktor pertama dapat dikatakan sebagai kelompok faktor yang paling dominan terhadap keputusan pemilihan sekolah dasar di Kota Surakarta. Kelompok faktor 
Resty Darma Saputri dkk, Faktor-faktor yang Mempengaruhi... pertama lebih merepresentasikan terpenuhinya indikator terkait sekolah ramah anak dengan sub-faktor ketersediaan sarana dan prasarana ramah anak, proses belajar mengajar yang ramah anak, adanya partisipasi anak dalam kegiatan belajar mengajar, adanya kebijakan sekolah ramah anak, pendidik dan tenaga kependidikan terlatih hak-hak anak, dan adanya partisipasi pihak terkait dalam perwujudan sekolah ramah anak. Hasil ini mendukung hipotesis yang disebutkan pada latar belakang penelitian bahwa terdapat faktor lain selain besarnya jarak dari rumah ke sekolah dalam keputusan pemilihan sekolah dasar, dan faktor tersebut ialah terpenuhinya indikator sekolah ramah anak di sekolah dasar yang dituju.

Kelompok faktor kedua merepresentasikan lokasi dan jam belajar sekolah, dengan sub-faktor jarak dari rumah ke sekolah, tingkat aksesibilitas sekolah, lokasi sekolah aman dan nyaman, dan efektivitas waktu belajar mengajar.

Kelompok faktor ketiga merepresentasikan fasilitas tambahan yang tidak disediakan oleh semua sekolah, yakni ketersediaan sarana transportasi umum dan adanya program makan siang di sekolah. Kelompok faktor ketiga tidak terlalu berpengaruh dalam keputusan pemilihan sekolah dasar bila dibandingkan dengan kedua kelompok faktor sebelumnya.

\section{REFERENCES}

Andryana, S. (2009). Analisa Faktor-Faktor Yang Mempengaruhi Pemilihan Sekolah Dasar Di Kota Depok Menggunakan Metode Proses Analisa Bertingkat. Jurnal Basis Data, ICT Research Center UNAS. ISSN, 9483.

Kementerian Pemberdayaan Perempuan dan Perlindungan Anak. 2011. Kabupaten/Kota Layak Anak: Bahan Advokasi Kebijakan KLA

Kementerian Pemberdayaan Perempuan dan Perlindungan Anak. 2011. Peraturan Menteri Pemberdayaan Perempuan dan Perlindungan Anak Nomor 12 Tahun 2011 mengenai Kriteria Kota Layak Anak

Khasanah, N. (2012). Faktor-Faktor yang Mempengaruhi Orang Tua dalam Pengambilan Keputusan Memilih Sekolah Dasar Swasta (SD Virgo Maria 2 dan SDIP. H. Soebandi Kecamatan Bawen Kabupaten Semarang). Jurnal Universitas Satya Widya, 28(2), http://dx.doi.org/10.24246/j.sw.2012.v28.i2.p137-146

Kristiani, N. (2016). Faktor-Faktor yang Mempengaruhi Keputusan Orang Tua Siswa Memilih SD Kasatriyan Surakarta. Jurnal Manajemen Maranatha, 16(1)

Patilima, Hamid. 2008. Kota Layak Anak. http://ykai.net. Diakses tanggal 5 November 2017

Pemerintah Kota Surakarta. Surakarta Kota Layak Anak. http://surakarta.go.id/?p=6471. Diakses tanggal 9 Oktober 2017

Perry, Clarence. 1929. The Neighbourhood Unit. London: Routledge

Porteous, J. Douglas. 1977. Environment and Behaviour: Planning and Everyday Urban Life. Massachusetts: Addison-Wesley Publishing Company

Rini, Erma F., Putri, Rufia A., Mulyanto, \& Handayani, N. 2017. Ecological Impact of Primary Education Facilities Based on Child Friendly Neighbourhood Unit Criteria in Surakarta. International Conference on Climate Change: Challenge and Opportunity on Environment Degradation Research. Solo, Indonesia 
Region, Vol. 13, No.2, Juli 2018: 152-168

Septhevian, Rani. (2014). Faktor-faktor yang Mempengaruhi Keputusan Orangtua dalam Memilih Sekolah Dasar (SD). Jurnal Magister Manajemen Universitas Atma Jaya Yogyakarta. p.1-14

UNICEF Innocenti Research Center. 2011. What is a Child Friendly City? http://childfriendlycities.org/overview/what-is-a-child-friendly-city/. Diakses tanggal 5 November 2017 